\title{
Urobilinogen Measurement
}

National Cancer Institute

\section{Source}

National Cancer Institute. Urobilinogen Measurement. NCI Thesaurus. Code C64816.

A quantitative measurement of the amount of urobilinogen present in a sample. 